
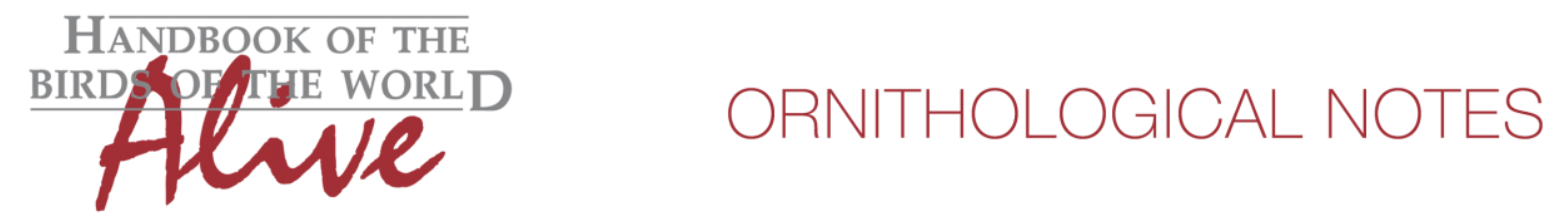

\title{
Notes on the vocalizations of Plain-crowned Spinetail (Synallaxis gujanensis), White-lored Spinetail (Synallaxis albilora) and Maranon Spinetail (Synallaxis maranonica)
}

Peter Boesman

In the following we briefly analyze and compare voice of (the different races of) Plaincrowned Spinetail (Synallaxis gujanensis), White-lored Spinetail (Synallaxis albilora) and Maranon Spinetail (Synallaxis maranonica). We also try to quantify the extent of any vocal differences using the criteria proposed by Tobias et al. (2010), as a support for taxonomic review.

We have made use of sound recordings available on-line from Xeno Canto (XC).

The analysis of voice of Plain-crowned and White-lored Spinetail is as much an exercise in finding the exact boundaries of the different voice types as it is a quantification exercise of the actual differences.

We can distinguish 5 voice types:

'gujanensis voice'

Song consists of 2 well-spaced nasal notes (actually, on a sonogram it is clear that the first note is followed immediately by a subdued lower-pitched 'rebouncing' note). First note is round overslurred, loudest in amplitude and highest in frequency. 'KEWeh....kweh' (Figure 1). This voice type can be heard in the following regions: All areas $\mathrm{N}$ of the Amazon, including along the line Leticia - Iquitos - Ecuador and N into Colombia. In NE Peru it would seem that the Rio Marañon is the southern limit. $S$ of the Amazon in Brazil, it occurs in most of the Amazon basin (extreme SW Pará is simoni, another voice group) at least as far west as the Rio Ituxi / Rio Purus confluence. This concurs with races columbiana, gujanensis and 'northern part of huallagae'.

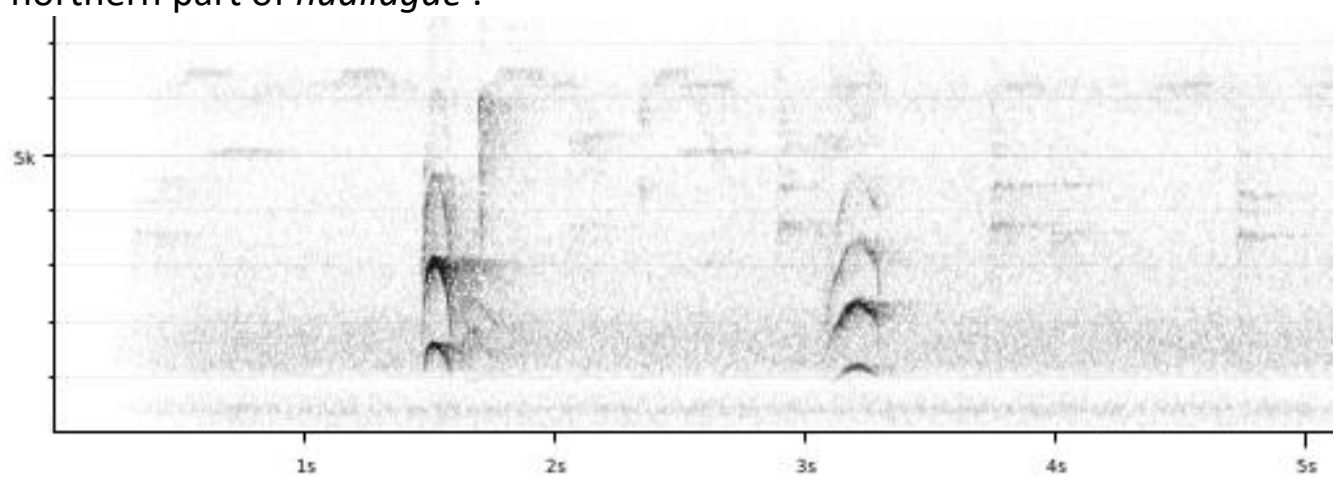

Figure 1: typical song of gujanensis group

Measured parameters:

first note: length $0.094-0.12 \mathrm{~s}$ and max. freq. $1420-1700 \mathrm{~Hz}$ (round and overslurred) last note: length $0.16-0.23 \mathrm{~s}$ and max. freq. $1200-1470 \mathrm{~Hz}$ (round and slightly rising) 

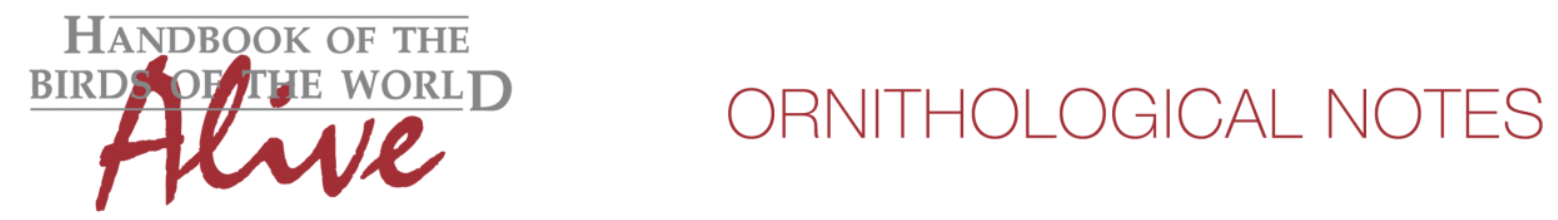

\section{'west Amazonian voice'}

Song is a rhythmic series of 3 nasal notes, with a longer pause after the first note. First note is longest and downslurred, third note is sharply rising (Figure 2).

This voice type can be heard in the following regions: in E Peru from Tarapoto south into Bolivia. This concurs with 'southern part of huallagae', canipileus, inornata, and certhiola. What is presently known as the race huallagae seems to be more than one vocal group, with the Rio Marañon as the apparent boundary (or the distribution of huallagae is different from what is presently assumed).

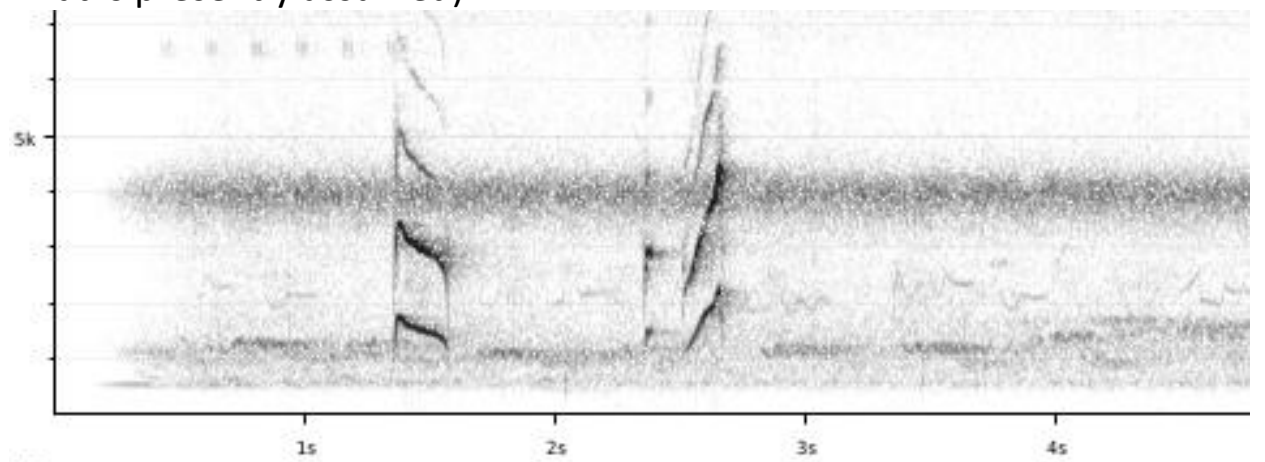

Figure 2: typical song of west Amazonian group

Measured parameters:

first note: length $0.2-0.23 \mathrm{~s}$ and max. freq. $1700-1900 \mathrm{~Hz}$ (downslurred)

last note: length $0.14-0.17 \mathrm{~s}$ and max. freq. $1850-2300 \mathrm{~Hz}$ (sharply upslurred)

\section{'albilora voice'}

Song is a rhythmic series of 3 nasal notes, with a longer pause after the first note. First note is usually shortest and sharply downslurred, third note is long and rising (Figure 3).

This voice type can be heard in the following regions: $S$ Matto Grosso and Mato Grosso do Sul. Voice of albilora, while similar in rhythm to west Amazonian voice, can easily be separated from these races: first note is longer and is the highest in frequency, last note is also longer and is the lowest in frequency. Also second note is slightly different.

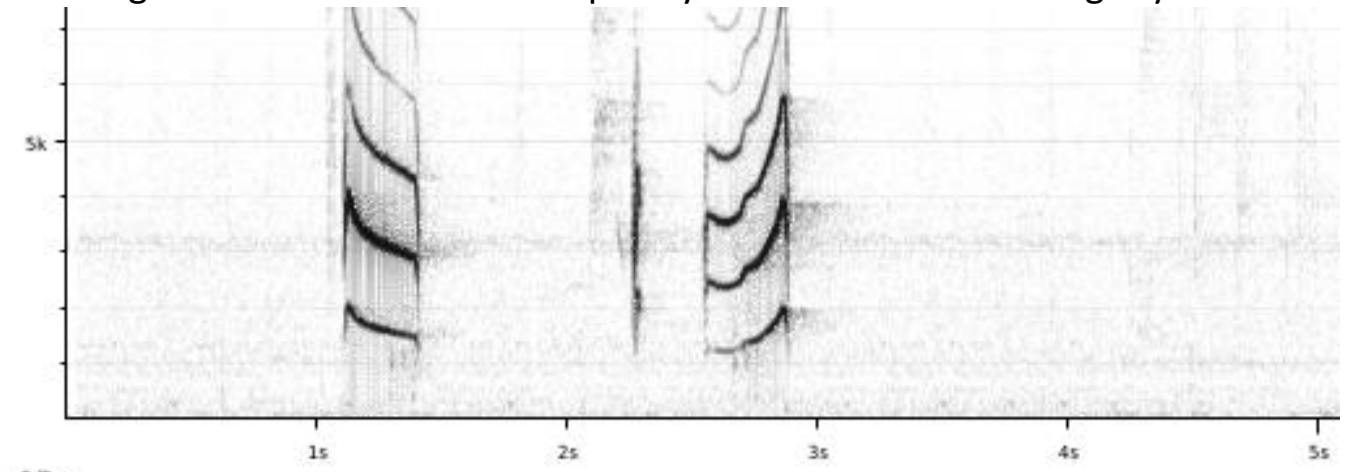

Figure 3: typical song of albilora

Measured parameters:

first note: length $0.23-0.28 \mathrm{~s}$ and max. freq. $2200-3000 \mathrm{~Hz}$ (downslurred) last note: length $0.19-0.34 \mathrm{~s}$ and max. freq. $1800-2300 \mathrm{~Hz}$ (sharply upslurred) 


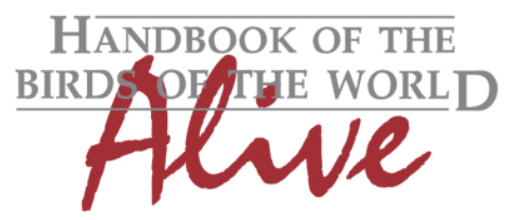

\section{ORNITHOLOGICAL NOTES}

'simoni voice' ('Araguaia Spinetail')

Song consists of a single note, occasionally interspersed with a rhythmic double note (in this case, rhythm quite similar to albilora). All long notes are however downslurred (never upslurred) (Figure 4). Voice similar to first note of 'albilora voice' and 'west Amazonian voice' but longer.

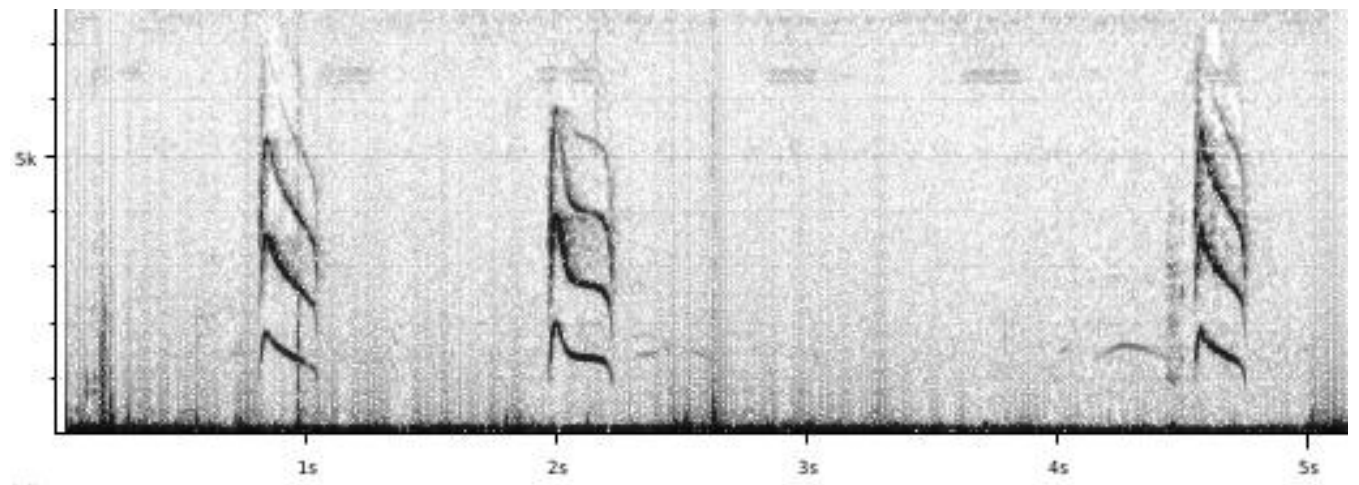

Figure 4: typical song of simoni

Measured parameters:

first note: length $0.26-0.36 \mathrm{~s}$ and max. freq. $1600-2000 \mathrm{~Hz}$ (downslurred)

'maranoni voice'

Song consists of two long notes, sometimes second note preceeded by a short note, resulting in a rhythm similar to albilora. Note shape of first note very recognizable, sharply rising and falling, last note long and slurred downward (Fig. 5).

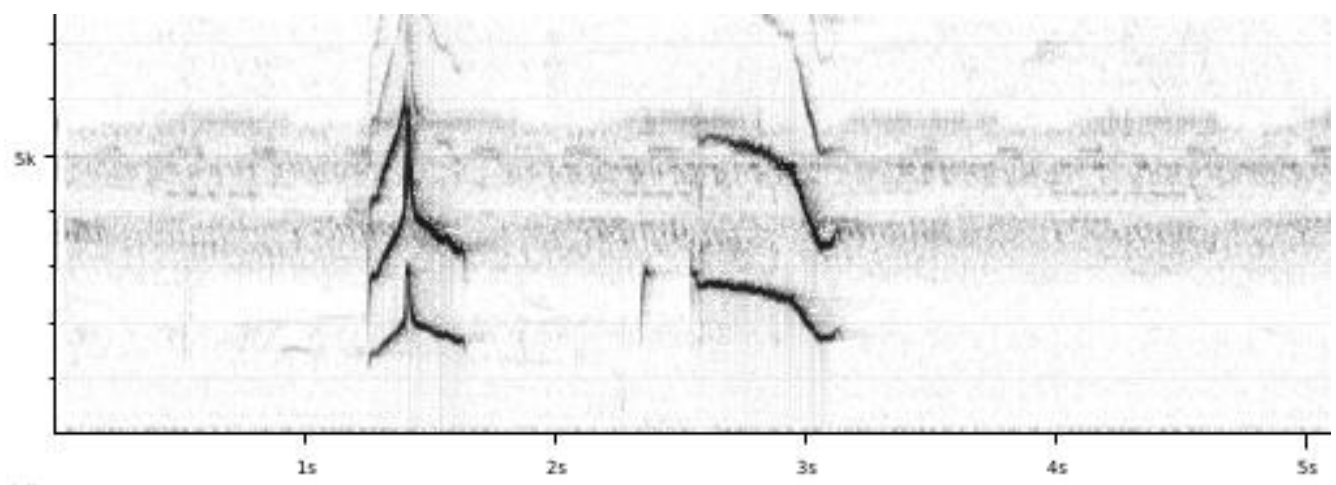

Figure 5: typical song of maranoni

Measured parameters:

first note: length $0.4-0.43 \mathrm{~s}$ and max. freq. $2700-3150 \mathrm{~Hz}$ (rising/falling)

last note: length $0.45-0.62 \mathrm{~s}$ and max. freq. $2800-2900 \mathrm{~Hz}$ (long and downslurred) 

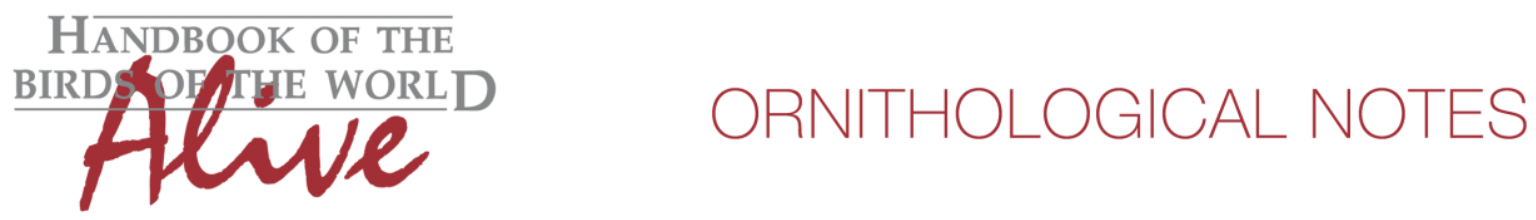

Conclusion:

The voices which are standing most apart are:

'gujanensis voice' because of its very different rhythm, shortest loud notes (score 3) and lowest max. frequencies (score 3 ) and the unique 'echoing or rebouncing note' and round overslurred note shape (1). This would lead to a total vocal score (vs all other groups) of about 6 when applying Tobias criteria.

'maranoni voice' because of its spiky note shape, longest loud notes (score 3) and highest maximum frequencies (score 2), resulting in a total vocal score of 5 vs all other groups.

The 3 remaining voice groups could be scored as follows:

'simoni voice' differs from both others in lower average number of notes (score 2), lack of upslurred notes (score 1 or 2 ) and longer downslurred notes (score 1). Total score 3 or 4.

'albilora voice' differs from 'west Amazonian voice' by having longer notes (score 1 or 2) and reaching higher frequencies (score 1 or 2), with further differences in note shape and location of highest frequency. Total score about 3.

This note was finalized on 29th April 2015, using sound recordings available on-line at that moment. We would like to thank in particular the many sound recordists who placed their recordings for this species on XC.

\section{References}

Tobias, J.A., Seddon, N., Spottiswoode, C.N., Pilgrim, J.D., Fishpool, L.D.C. \& Collar, N.J. (2010). Quantitative criteria for species delimitation. Ibis 152(4): 724-746.

\section{Recommended citation}

Boesman, P. (2016). Notes on the vocalizations of Plain-crowned Spinetail (Synallaxis gujanensis), White-lored Spinetail (Synallaxis albilora) and Maranon Spinetail (Synallaxis maranonica). HBW Alive Ornithological Note 102. In: Handbook of the Birds of the World Alive. Lynx Edicions, Barcelona. (retrieved from http://www.hbw.com/node/932007 on 22 July 2016). 